\title{
Archaeoentomological Perspectives on Dorset Occupations in Newfoundland: A Case Study from the Site of Phillip's Garden (EeBi-1)
}

\author{
Frédéric Dussault, ${ }^{1,2}$ Trevor J. Bell ${ }^{3}$ and Vaughan Grimes ${ }^{1}$
}

(Received 22 February 2016; accepted in revised form 24 October 2016)

\begin{abstract}
The Dorset Paleo-Inuit occupied the island of Newfoundland for over 800 years (1990 BP to 1180 BP), producing a unique and identifiable archaeological record. Despite this, our current understanding of this sea-mammal hunting population is essentially based on past analysis of architecture, artefacts, and animal remains. While these data show that the Dorset intensively used sites at different locations through the Arctic and Subarctic, very little information is known regarding their impact on their surroundings and the environment. Our research is based on soil samples collected at the site of Phillip's Garden, which is considered to be one of the most intensely occupied sites within the Dorset culture's geographic range. Beetles, which are known to be ecological specialists, were used as a proxy in this research in order to document the composition and fluctuation in vegetation, and environmental change through time at the site. The analysis demonstrates that the Dorset communities of Phillip's Garden harvested trees, and modified the environment and the flora surrounding their settlement more intensively than previously thought.
\end{abstract}

Key words: archaeoentomology; Dorset; Newfoundland; land-use; landscape; economy; hunter-gatherer

RÉSUMÉ. Entre 1990 AA et 1180 AA, l'île de Terre-Neuve a connu une période d'occupation de plus de 800 ans par la culture dorsétienne. Cette occupation, documentée dans les données archéologiques, a laissé des traces uniques et visibles. Malgré cette richesse archéologique laissée par les Dorsétiens, notre compréhension de cette culture axée sur la chasse aux mammifères marins est principalement basée sur les données architecturales, artéfactuelles et zooarchéologiques. Ces données ont permis de démontrer que la culture dorsétienne a occupé de façon très intensive plusieurs sites localisés dans l'Arctique et le Subarctique. Cependant, peu d'informations sont fournies par ces données quant à l'impact de cette culture sur son environnement et ses lieux d'occupation. Les données utilisées au cours de notre recherche ont été récupérées dans des échantillons de sols ayant été prélevés sur le site de Phillip's Garden, considéré comme l'un des sites les plus intensément occupés par la culture dorsétienne. En tant que spécialistes de leur niche écologique, les coléoptères ont été utilisés dans cette recherche afin de documenter la composition et les modifications visibles dans la végétation du site à travers le temps. Cette analyse permet de changer notre perception de l'étendue des modifications faites à la flore et à l'environnement par les Dorsétiens établis au site de Phillip's Garden, modifications dues entre autres à l'exploitation des arbres.

Mots clés: archéoentomologie; Dorset; Terre-Neuve; utilisation du territoire; paysage; économie; chasseurs-cueilleurs

Révisé pour la revue Arctic par Nicole Giguère.

\section{INTRODUCTION}

The Dorset Paleo-Inuit established themselves in a wide variety of environments. They migrated from the Eastern Canadian Arctic to as far south as the islands of St. Pierre and Miquelon off the southeast coast of Newfoundland (Raghavan et al., 2014). Close to the southernmost extent of their range, the island of Newfoundland, with its different terrestrial biomes and the boreal forest that covers most of its surface, is contrastingly different to the High Arctic for which the Dorset culture and technology were initially adapted.
The site of Phillip's Garden, on the Northern Peninsula of Newfoundland, is well known for its Dorset occupation (1990 BP to 1180 BP) (Fig. 1a) (Renouf, 2011b). First identified early in the 20th century by Howley (1915) and excavated by Harp in the 1950s, this site has been the focal point of several field seasons and many researchers since 1982 (Harp, 1950, 1951; Renouf, 2011a). In collaboration and under the supervision of Dr. Renouf, these researchers studied the Dorset artefacts and structures uncovered at the site in order to better our understanding of the Dorset culture, their way of life, and the reasons for their disappearance from Newfoundland. Results of this

\footnotetext{
${ }^{1}$ Department of Archaeology, Queen's College, Memorial University of Newfoundland, St. John's, Newfoundland and Labrador A1B 3R6, Canada

${ }^{2}$ Corresponding author: dussault.fred@gmail.com

${ }^{3}$ Department of Geography, Memorial University of Newfoundland, St. John's, Newfoundland A1B 3X9, Canada

(C) The Arctic Institute of North America
} 


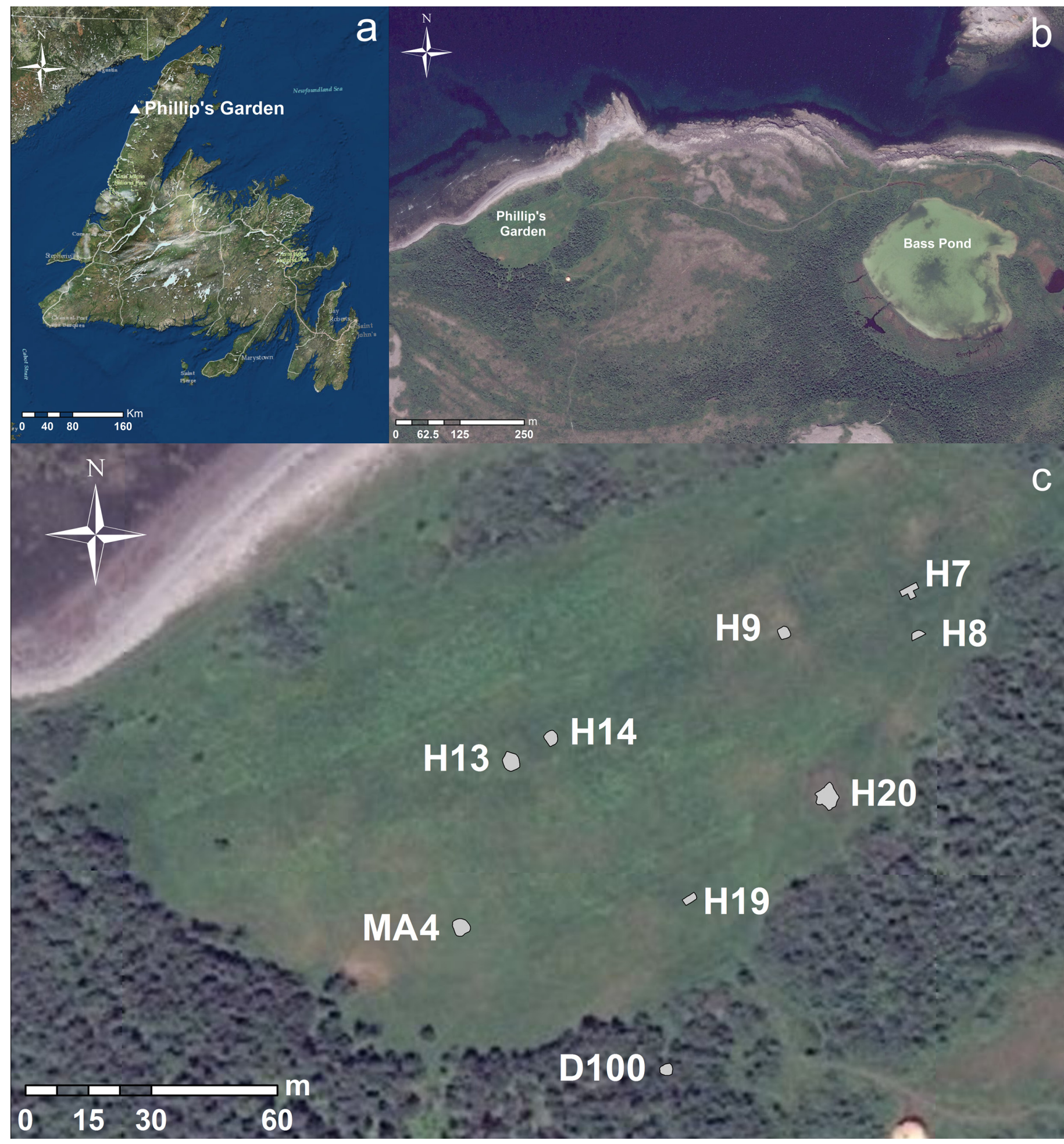

FIG. 1. Maps of Newfoundland, showing (a) the location of Phillip's Garden on the Port au Choix Peninsula, (b) the location of Bass Pond in relation to Phillip's Garden, and (c) the features in the Meadow of Phillip's Garden that are discussed in the paper. On maps (b) and (c), the darker shade surrounding the meadow represents the stunted pine forest known as tuckamore.

research, which encompasses a variety of academic fields, depicts a culture that was highly adapted to the marine environment. These Dorset people lived on the shores of the Strait of Belle-Isle and took advantage of the harp seal migration (Renouf, 1993, 1999). A warming climate that reached its peak around $1100-1000 \mathrm{BP}$, and diminishing sea ice that rendered the seal hunt more unpredictable, were later proposed as an explanation for their disappearance in Newfoundland (Bell and Renouf, 2008; Renouf and Bell, 2009).

In contrast with other regions of the Eastern Canadian Arctic where sites associated with the Early Dorset through 
the Late Dorset are found, only the Middle Dorset period (1990-1180 BP) is found in Newfoundland (Renouf, 2003). The Middle Dorset period is subdivided into the Early phase (1990-1550 cal BP), the Middle phase (1550-1350 cal BP), and the Late phase $(1350-1180 \mathrm{cal} \mathrm{BP})$. The subdivision of the Middle Dorset (Early, Middle, and Late phases) was proposed by Renouf and Bell (2009) based on over 30 radiocarbon dates obtained from 15 dwellings at Phillip's Garden (Renouf, 2011c). At the site of Phillip's Garden, archaeologists have already demonstrated the intensity of occupation during the Middle phase, which is visible in the archaeological record through the number of houses, but also through the larger size of houses dated to this period (see Renouf, 2003; Erwin, 2011).

Even though a great number of researchers have looked at Dorset hunting practices, tool-making processes, architecture and social organization, little is known of their use of the terrestrial landscape and resources available around their settlements. This lack of information on the relationship with their immediate environment is partly due to the paucity of organic proxies found in the Arctic, and the generally poor preservation of plant remains in Newfoundland due to the acidic soil found in most regions of the island. However, Phillip's Garden is spared from this poor preservation due to its limestone bedrock, which neutralizes this acidity (Wells, 2011:67). Other than bones and stones, very few types of material are preserved on prehistoric sites in Newfoundland unless the site has very specific preservation conditions, such as the Paleo-Inuit steatite quarry of Fleur-de-Lys, where wood was very well preserved in waterlogged contexts (Erwin, 2001; Renouf et al., 2009).

The present research documents the Dorset population's use of terrestrial resources available in their surroundings at Phillip's Garden by using novel proxy data in Newfoundland; insect remains preserved in archaeological soil. Chitin, the substance composing insect exoskeletons, is resistant to many environmental conditions and can be preserved in soil for thousands of years, allowing the identification of the insect from which it originated (Elias, 1994, 2008, 2010). Since insects have not evolved in the last two million years, it is therefore possible to project known ecological preferences and requirements of modern insect's ecological niches to archaeological remains found during analyses (Coope, 1978; Elias, 2010). Archaeoentomology was first used in the United Kingdom and later spread to other parts of the world (Coope, 1959; Coope and Osborne, 1967; Bain and Prévost, 2010; King and Bain, 2011; Vickers and Panagiotakopulu, 2011; Forbes et al., 2014; Panagiotakopulu, 2014). Archaeoentomological research has been used in different contexts, providing a wide variety of information on past human occupations. For more on the history of archaeoentomological research in the North Atlantic, including ancestral Inuit occupations, see Forbes et al. (2014).

By using entomological remains, and the information provided from their identification, we were able to tackle different research questions concerning the Dorset way of life. The first objective of this research was to evaluate the capacity of archaeoentomology to assess huntergatherer occupations in Newfoundland. Also, by using entomological remains found at the site of Phillip's Garden, it was possible to document Dorset use of plant material for purposes other than food, such as fuel or building material. Finally, we explored how the intensity of the Middle Dorset occupation phase impacted the surrounding environment compared to the less populated Early and Late phases. We also try to determine the duration of the changes they generated in the environment over the occupation span, and if these traces are still visible on the landscape today.

\section{LITERATURE REVIEW}

Until recently, research has rarely explored the possibility of landscape modification and ecological change caused by the presence of hunter-gatherer populations in North America (Thompson and Waggoner, 2013). In the North Atlantic, the body of work on anthropogenic and ecological changes due to or enhanced by human activities and cultural practices has mostly focused on Norse populations and other agro-pastoral occupations (Amorosi et al., 1997; Simpson et al., 2001; Panagiotakopulu and Buckland, 2013; Forbes et al., 2014; Ledger et al., 2014; Panagiotakopulu and Buchan, 2015). Human establishments in these "pristine" environments had a profound and marked effect on the fauna and flora (Amorosi et al., 1997; Dugmore et al., 2005). In contrast, Native American cultural groups, including the First Nations and ancestral Inuit, are often assumed by non-archaeologists to have very little to no impact on their environment (Billington, 1981; Dickason, 1997). Recent research focusing on small-scale economies in different parts of the world tends to paint a different portrait of the impact of these Aboriginal peoples. For example, huntergatherer groups living in the Arctic and elsewhere in North America are found to have noticeably influenced their immediate environment following years of occupation and hunting-gathering activities (Thompson and Waggoner, 2013).

Several researchers working in the Arctic observed the development of deeper soil on archaeological sites compared to the surrounding environment (Lutz, 1951; McCartney, 1979; Moore, 1986; Moore and Denton, 1988; Forbes, 1996). In his paper on Thule archaeological sites on Devon and southwestern Cornwallis Islands, Forbes (1996) demonstrated that past human occupations influenced the growing cycle of plant communities after occupation. He also noted that house pits associated with Thule Inuit had a lush vegetation in comparison with the barren surrounding environment. Similar observations have been made in Nunavik, Canada, near Kangiqsujuaq, at the site of La Rivière aux ossements (JiEv-15) (Saunitarlik). This hunting site, used from the end of the 19th century to the mid 20th century, consists of a small brook with shores littered 
with thousands of bones. Increased available nutrients from butchering practices altered soil composition, and this enrichment of nutrients resulted in vegetation that is richer, more diversified, and lusher than that on the general surroundings (Bernier, 2014). Although both these analyses examined Thule and Inuit sites, which are more recent than the Dorset site of Phillip's Garden, research focusing on the soil composition of a Dorset component at the site of Arnaqquaksaat, on the southwestern tip of Igloolik Island, Canada, demonstrated that soil development, vegetation growth, and soil chemistry were influenced by direct and indirect human habitation and animal activities (Derry et al., 1999). The anthropogenically enriched "upslope" area of the sites had a significantly deeper soil than the uninfluenced areas (Derry et al., 1999).

Because of its location, the island of Newfoundland has several different ecoregions and forest types (Damman, 1983; Boland, 2011). On the basis of climate, Damman (1983) divided the island into nine different ecoregions. Phillip's Garden and the Port au Choix Peninsula are located at the junction of the Strait of Belle-Isle ecoregion and the Northern Peninsula forest ecoregion. This means the site of Phillip's Garden is a blend of coastal barrens and boreal forest vegetation. Coastal barrens are found on limestone subsoils and characterized by open woodlands and heath lands composed of small shrubs, such as juniper and willow (Bell and Renouf, 2011). The wet boreal forest characterizing the Northern Peninsula is composed of balsam fir and spruce. The region's lack of forest fires has affected the type of vegetation found; balsam fir composes most of the boreal forest, while black spruce is usually found in wetter areas (Bakuzis and Hansen, 1965; Thompson et al., 2003). At Phillip's Garden, Renouf (2011b) suggested that the intensity of occupation affected the environment by creating a grassy meadow. Environmental analysis undertaken at the Bass Pond site, located $500 \mathrm{~m}$ from Phillip's Garden (Fig. 1b), used cores taken in the pond sediments. The pollen recovered from the cores demonstrated human impact on the immediate environment of the pond (Bell et al., 2005; Renouf et al., 2009). However, when comparing the human impact on the pollen record between Amerindian and Paleo-Inuit occupations, Renouf et al. (2009) mention that only the activities undertaken on the edge of Bass Pond, such as wood burning, wood working and seal skin soaking, are recorded for the Paleo-Inuit occupations. Although it is not visible in the palynological record, Renouf's interpretation that the meadow of Phillip's Garden was created by human occupation could be based on field observations.

Similarly, archaeologists working in the Arctic and Subarctic often use vegetation to locate human settlements and structures (Anderson and Freeburg, 2014). One of these methods suggests that the presence of lush, dense vegetation on and in the house depressions could be associated with house features (Renouf, 1985; Robinson, 2014). The site of Phillip's Garden corroborates this assumption. Over many years and numerous field seasons, Renouf noticed that Dorset features could easily be seen by the trained eye in the meadow of Phillip's Garden, since it has been demonstrated that iris flowers often demarcate the central depressions of Dorset dwellings (Renouf, 1985; Robinson, 2014). This observation is a first step in our understanding of the environmental impact of the Dorset occupation at the site of Phillip's Garden.

\section{ARCHAEOENTOMOLOGY}

As they are found in specific ecological niches, beetles require particular environments and conditions to live, thrive, and reproduce. These preferences, in terms of ecological requirements, will be the foundation of our reconstruction. Hence, the presence of a single specimen found in the archaeological soil may be significant, as it could not have been present without either its ecological requirements close to the site or human presence to transport it to the location. Although the presence of single specimens was considered, the interpretation of the site is based on the ecological groupings of insects and the changes through time. The analysis and interpretation of the site were undertaken using the minimum number of individual (MNI) insect species associated with the different environments. Since each insect has the same number of body parts ( 1 head, 1 pronotum, 1 left and right elytron), the minimum number of insects is easily calculated.

Prior to the 1970s, climatic reconstruction principally used pollen and plant remains as proxies, but the introduction of entomological analysis in that decade demonstrated that insects were better suited to the study of rapid changes in climate (Coope and Brophy, 1972; Atkinson et al., 1987; Elias, 2010). Although their first uses were in geographically broad climatic reconstructions, insect remains proved to be a reliable source of data on past environmental conditions at a local scale. Since they are ecological specialists, their presence in archaeological contexts can be used to reconstruct past environments, as well as changes in the local environment. The scale of data they provide is local, but it is also possible to infer a wider, regional portrait by combining local studies (Elias, 2010).

\section{Sampling Procedure}

The sampling method used for this research broadly follows Elias (2010), Kenward (2009), and Buckland and Sadler (2000). Samples (3 L in volume) were collected using a clean trowel to avoid cross-contamination between layers. First, the surface to be sampled was cleaned by removing the top centimetre of soil. Then each $3 \mathrm{~L}$ sample was collected and placed in a double plastic bag. To increase traceability, we attached two identification tags, one inside the inner bag containing the sample, and the other between the inner and outer bags. The samples were stored in the now defunct North Atlantic Archaeology Laboratory facility 
TABLE 1. Radiocarbon dating results for the features analyzed during the research. Samples processed at Beta Analytics.

\begin{tabular}{|c|c|c|c|c|c|c|}
\hline House \# & Lot \# & $\mathrm{Lab} \#$ & Measured age & Median cal. BP rounded & $1 \sigma$ rounded & $2 \sigma$ rounded \\
\hline House 7 & 7A363D 9 & Beta 355116 & $1560 \pm 30$ & 1470 & $1410-1520$ & $1390-1530$ \\
\hline House 8 & 7A357C 56 & Beta 355115 & $1670 \pm 30$ & 1580 & $1580-1610$ & $1520-1690$ \\
\hline House 9 & $7 \mathrm{~A} 342 \mathrm{D} 10$ & Beta 355114 & $1710 \pm 30$ & 1610 & $1560-1690$ & $1550-1700$ \\
\hline House 13 & $7 \mathrm{~A} 264 \mathrm{C} 15$ & Beta 355110 & $1490 \pm 30$ & 1370 & $1350-1400$ & $1310-1510$ \\
\hline House 14 & 7A285A 5 & Beta 355111 & $1540 \pm 30$ & 1450 & $1390-1520$ & $1370-1520$ \\
\hline House 19 & $7 A 290 B 6$ & Beta 355112 & $1600 \pm 30$ & 1480 & $1420-1540$ & $1410-1550$ \\
\hline House 20 & 7A310B 18 & Beta 355113 & $1630 \pm 30$ & 1530 & $1420-1560$ & $1420-1600$ \\
\hline MA4 & $7 \mathrm{~A} 241 \mathrm{~A} 8$ & Beta 355109 & $1780 \pm 30$ & 1700 & $1620-1730$ & $1370-1520$ \\
\hline D100 & Off grid & Beta 355126 & $1450 \pm 30$ & 1340 & $1310-1360$ & $1300-1390$ \\
\hline
\end{tabular}

in Memorial University until they were processed. The laboratory methods used for the current project were first described by Coope and Osborne (1967), later documented by Kenward et al. $(1980,1985)$, and subsequently modified by Bain (2001). Once separated using kerosene flotation, the light fraction was preserved in alcohol in order to prevent the growth of mould. Insects were sorted and identified using a low-magnification stereoscope. To identify the entomological remains, we used reference literature, highdefinition pictures, and the reference collections of the Canadian National Collection of Insects, Arachnids, and Nematodes in Ottawa, located at the Agriculture and Agrifood Canada Central Experimental Farm.

During the field season of 2013, samples were gathered from the test pits excavated by the Port au Choix Archaeological Project. The objective of the field season was to test features located in the meadow and obtain radiocarbon-datable material in order to refine the chronology of the site (Wells et al., 2014). Radiocarbon dates, obtained from charcoal samples found in the test pits, are presented in Table 1. The sampling method for archaeoentomological research was adapted to this objective, therefore making it possible to test multiple structures and to position our data within a strong chronological framework. Seven houses identified and excavated by Harp (1976) will be discussed, as well as two buried features. The definition of dwellings at Phillip's Garden originally defined by Harp (1976) was subsequently refined by Renouf (2011c), who describes the semi-subterranean winter dwellings found at Phillip's Garden as a single room, varying in shape, oval or rectangle, with side and rear platforms made of stacked limestone shingles and a northeast entrance facing the sea. The footprint of these structures varied greatly, from $28.3 \mathrm{~m}^{2}$ upward to more than $105 \mathrm{~m}^{2}$ (Renouf, 2011c). Although the structures that were studied in the present research had been previously excavated, sections of the houses had been left intact. Those intact house sections were meant to allow future research, and test pits were dug in those sections to gather both the radiocarbon and the archaeoentomological samples. Four levels were identified during the excavation. Level 1, the highest level in the stratigraphy, is close to the surface and composed of the root mat of the present vegetation. Level 2 corresponds to the overburden layer of the archaeological structure and was formed following the occupation and abandonment of the features. Level 3 is the occupation layer of the different features, recognized by its darker shade and its greasiness. This layer, found on the pavement of many features and in the middens, contains most of the artifacts associated with the Dorset. Level 4, the lowest point in the stratigraphy, is composed mostly of beach sand and cobble, and it is also found under structures such as pavements and platforms.

To the features that were previously excavated by Harp, we added two features that were tested in 2013 and yielded interesting information on Phillip's Garden. The first buried feature (MA4) was found via magnetometric survey, and the second one (D100), a visible surface depression, was found at the edge of the site (Fig. 1c). Associated with the late Phase of the Middle Dorset occupation of Phillip's Garden, Depression 100 is located off the grid established at the site by Parks Canada. The location of this feature, which was found in the tuckamore (a local term used to describe isolated thickets of pine and fir) surrounding the site, suggests that the site was larger at the time of occupation than initially thought, but that the tree line changed after the site was abandoned and encroached on the structures located at its margins.

\section{RESULTS}

The soil matrix was documented during laboratory analyses. The soil encasing the entomological remains was organic in nature with particles larger than 150 microns. Silt $(4-62.5 \mu \mathrm{m})$ and clay $(0.98-3.9 \mu \mathrm{m})$ are mineral in nature and of such a fine size that the size of mesh used during the archaeoentomological analysis $(150 \mu \mathrm{m})$ allows them to be washed away during the water treatment of the samples. The heavy fraction (material remaining after the kerosene flotation) found in level 4 was highly mineral in nature; sand composed the largest part of the samples, as well as small beach pebbles. The level 3 heavy fraction also contained sand, but in a smaller quantity (less than $20 \%$ ), with the remainder of the fraction composed of highly degraded and decomposed organic material, such as plant fibers and leaves. The level 2 heavy fraction contained almost no sand (less than 5\%) and was composed of organic material (decomposed leaves and plant fibers), but also contained small branches and twigs. Close to the surface, level 1 had very little sand (less than $5 \%$ ), and most of the fraction was decaying vegetation and small roots. 


\section{Changes through Time}

To help interpret the site's environment, the entomological identifications (Tables 2 and 3) were entered in the BugsCEP database developed by Buckland and Buckland (2006). This database classifies insects in ecological groupings and enables a quick visualization of the changes happening through time within the archaeoentomological data. Information on the ecological preferences of the different insects that were recovered during the analysis can be found in Table 4 . We compiled Figure 2 via the BugsCEP database by using its bugs EcoCodes. Although BugsCEP is mostly adapted to northern Europe, the species included in the database have the same ecological requirements independently of their geographical location, which allowed us to use this tool in our analysis of the site in Newfoundland. In order to show changes in the environment of the site, we have included four ecological niches in this graph (description of the niches taken from Buckland, 2007):

\begin{abstract}
Meadowland: Natural grassland or near equivalents. Open landscape.

Wetland/marshes: Water tolerant but not living specifically in the water. May include mud and bank species, as well as moss \& reed-dwellers that prefer permanently wet environments.

Open wet habitat: Hydrophilous shade intolerant species, shingles, beaches, and other exposed wet environments.

Dung/foul habitat: A wide category for species that live in decaying, muddy and fetid environments, including compost, wet hay, dung and muddy edges of water.
\end{abstract}

(Buckland, 2007:101-102)

Insects used in the graph can be assigned to more than one habitat (Buckland, 2007). Although dung is included as a habitat, no insect species found during the analysis was specifically associated to its presence at the site. We calculated the value for each environment using the species attribution to the different EcoCodes, each species being worth one point (Fig. 2). By looking at the value of each EcoCode for a given sample, it is possible to perceive change in the environment through time.

In the different features that were analyzed, the lowest level (L4), which corresponds to the sterile beach sediment reached during the excavation, always had fewer specimens than L2 and L3. On top of the sterile beach level, the occupation layer (L3) has a generally dry environment and an increase in vegetation. The subsequent phase, which corresponds to an abandonment phase of the feature (L2), shows an increase in the number of taxa and species that reflect different ecological niches. Not only did we observe an increase in vegetation over the history of the site's occupation, but also an increase in the wet environment indicators, accompanied by an augmentation of dung/foul environment, which suggests the presence of decomposing organic material.
Wood-and Forest-Associated Beetles

As mentioned previously, insects allow us to detect the presence of wood and woodland environment. Ellychnia corrusca are associated with moist to wet environments, but are known to overwinter on trees (Rooney and Lewis, 2000). These insects were found in three different features we analyzed and are concentrated in the Early and Late phase features of the site. None of the Middle phase features presented insect species that are specifically associated with trees or a forested environment. Similarly, Depression 100 had tree-dwelling insect species (MNI 15), most of which were Scolytinae, or bark beetles (MNI 10). Bark beetles were found in the layer associated with the occupation of this feature (level 3), but were completely absent from the abandonment phase (level 2).

\section{DISCUSSION}

The first objective of this research was to evaluate how useful insect remains are for the study of huntergatherer occupations in Newfoundland. The occupation of Phillip's Garden did not allow the development of a synanthropic fauna; however, like other sites located in the Arctic, it did provide ecological niches differing from the natural environment (Forbes et al., 2014, 2015). Previous archaeoentomological analysis undertaken on PaleoInuit and Inuit sites demonstrated that higher densities of beetles associated with wastes are found in human-built environments than in the natural environment (Forbes et al., 2014, 2015). At Phillip's Garden, as well as the sites of Nunalleq, Alaska, and Qeqertasussuk, Greenland, rove beetles (Staphylinidae) were the most numerous family and seemingly thrived in the conditions provided by the dwellings (Böcher and Fredskild, 1993; Forbes et al., 2015). As Forbes et al. (2015) mentioned, the absence of synanthropic fauna on hunter-gatherer sites poses new challenges and questions for archaeoentomologists: why are they absent, and how can other insects, often seen as background fauna, provide valuable information on past human occupations?

Identification of entomological remains from the different samples demonstrates the impact of the Dorset occupation at Phillip's Garden. Dorset activities and occupation of the site affected the abundance of vegetation found in the meadow, as well as the humidity of the soil. Additionally, species associated with trees and forested environments were found in feature D100, which suggests the use of woodland resources by the Dorset at the time of occupation. The location of the structure, now in the forest, also suggests the encroaching of the forest on the site following its abandonment.

Previous research suggests that the Dorset people of Phillip's Garden used wood as a fuel source in addition to the blubber lamps that they are known to use (Miszaniec, 2014). Different hypotheses have been put forward to 


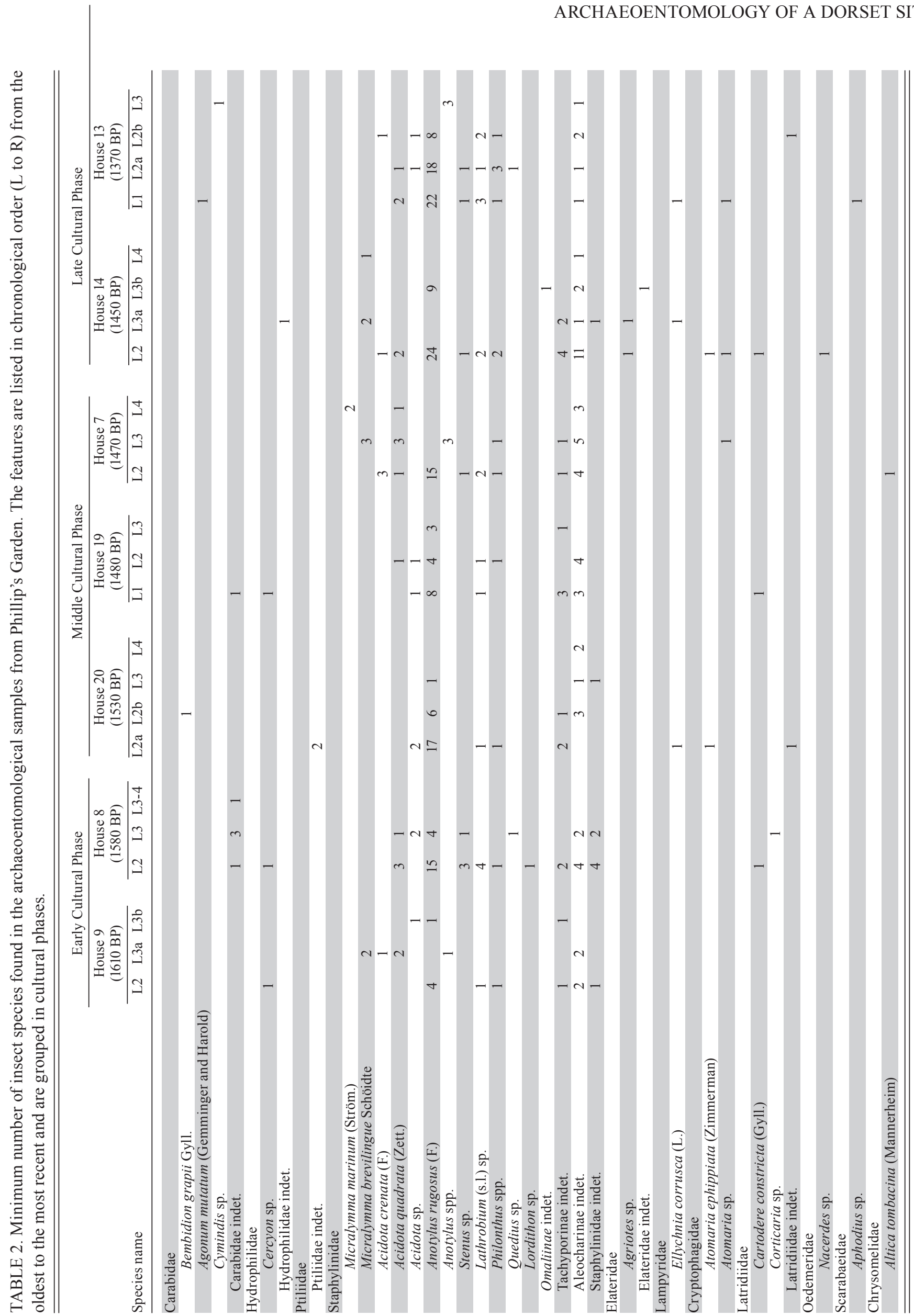


TABLE 3. Minimum number of insect species found in the MA4 and D100 features at Phillip's Garden.

\begin{tabular}{|c|c|c|c|c|c|c|}
\hline \multirow[b]{2}{*}{ Species name } & \multicolumn{3}{|c|}{$\begin{array}{c}\text { Middle Cultural } \\
\text { Phase } \\
\text { MA4 } \\
(1700 \mathrm{BP})\end{array}$} & \multicolumn{3}{|c|}{$\begin{array}{c}\text { Late Cultural } \\
\text { Phase } \\
\text { D100 } \\
(1340 \text { BP })\end{array}$} \\
\hline & L2a & $\mathrm{L} 2 \mathrm{~b}$ & $\overline{\mathrm{L} 3}$ & $\overline{\mathrm{L} 2}$ & L3 & L4 \\
\hline \multicolumn{7}{|l|}{ Carabidae } \\
\hline Clivina fossor (L.) & & 1 & & & & \\
\hline Bembidion spp. & & & & 2 & & \\
\hline Carabidae indet. & & & 1 & 7 & & 1 \\
\hline Dytiscidae indet. & & & 1 & & & \\
\hline \multicolumn{7}{|l|}{ Hydrophilidae } \\
\hline Cercyon pygmaeus (Ill.) & 2 & & & & & \\
\hline Cercyon sp. & 1 & & & 2 & & \\
\hline \multicolumn{7}{|l|}{ Ptiliidae } \\
\hline Ptiliidae indet. & & & & 1 & 2 & \\
\hline \multicolumn{7}{|l|}{ Staphylinidae } \\
\hline Micropeplus sp. & & & & 1 & 1 & \\
\hline Pseudopsis subulata (Herman) & & & & & 2 & \\
\hline Phloeonomus sp. & & & 3 & 4 & & \\
\hline Micralymma marinum (Ström.) & & & 3 & & & \\
\hline Acidota crenata (F.) & & & & 1 & & \\
\hline Acidota quadrata (Zett.) & & & & 1 & & 1 \\
\hline Acidota sp. & & & 1 & 4 & 3 & \\
\hline Anotylus rugosus (F.) & 12 & 4 & 5 & & & 2 \\
\hline \multicolumn{7}{|l|}{ Anotylus spp. } \\
\hline Stenus sp. & 1 & & & 8 & & \\
\hline Lathrobium (s.1.) sp. & 1 & 1 & 1 & 5 & & \\
\hline Philonthus spp. & 2 & & 1 & 5 & & \\
\hline \multicolumn{7}{|l|}{ Quedius sp. } \\
\hline Lordithon sp. & & & 1 & & & \\
\hline Tachyporinae indet. & 1 & 1 & 3 & 3 & & \\
\hline Aleocharinae indet. & 3 & 2 & 3 & 13 & 2 & 2 \\
\hline Staphylinidae indet. & 3 & & 8 & 12 & 3 & \\
\hline \multicolumn{7}{|l|}{ Elateridae } \\
\hline \multicolumn{7}{|l|}{ Elateridae indet. } \\
\hline Agriotes sp. & & 1 & & & & \\
\hline \multicolumn{7}{|l|}{ Buprestidae } \\
\hline Buprestis sp. & & & & & 1 & \\
\hline \multicolumn{7}{|l|}{ Cryptophagidae } \\
\hline Atomaria ephippiata (Zimme & rman) & & 1 & 1 & & \\
\hline \multicolumn{7}{|c|}{ Curculionidae } \\
\hline Dendroctonus simplex (Leco & nte) & & & & 1 & \\
\hline Polygraphus rufipennis (Kirl & & & & & 5 & \\
\hline Scolytidae indet. & & & & 1 & 4 & \\
\hline Hypera nigrirostris (F.) & & & 1 & & & \\
\hline
\end{tabular}

explain the variations in the use of wood as a fuel source: the scarcity of wood resources at Phillip's Garden, seasonality, and the cultural preference of the Dorset for blubber lamps (Miszaniec, 2014).

Entomological remains found in the different features analyzed at Phillip's Garden allow us to explore this topic. The identification of these remains demonstrates that houses associated with the Early and Late phases have insects indicating the presence of trees and a forested environment, while the Middle phase structures are devoid of the same species.

In order to understand wood use through time, it is necessary to look at the occupation phases and the known functions of the site. Previous research demonstrates without a doubt that the occupation of Phillip's Garden by the Dorset was highly focused on the exploitation of the harp seal herds migrating through the Strait of Belle Isle. As Renouf (2011c) argued, coordinated efforts were required to take advantage of this unusually rich resource, which was available for only a limited time each year. A larger human population allowed for a better and more successful hunt. Population estimates by different researchers demonstrate the importance of the Middle Dorset Middle Phase, which had the most dwellings occupied at the same time (Harp, 1976; Erwin, 1995, 2011; Renouf and Bell, 2009). These studies defined the occupation of Phillip's Garden from an initial low population (Early phase), to the population maximum (Middle phase), which was followed by a decrease and the abandonment of the site during the Late phase (Renouf, 2011c).

From their material culture and the animal remains found in the site, it was possible to see the importance of harp seals as a source of food and skins for clothing (Wells, 1988; Renouf, 1993, 2011c; Hodgetts, 2005a). The seal fat procured during the hunt also had an important role in Dorset daily life. Renouf (2011c) outlines its importance as a form of fuel, as food, and as a waterproofing agent for everyday objects used in the hunt, such as boots, sleds, and boats. This material was paramount in the Dorset economy, and it has permeated the soil of Phillip's Garden, giving it a unique greasy texture (Renouf, 2011c).

Looking at the Late Phase Dorset occupation at Phillip's Garden, it is possible to see that the occupants of the site turned to alternative resources in order to compensate for the diminished availability of seals. The analysis of faunal remains found in middens associated with the Late Phase at the site revealed greater quantities of small game animals, birds, and other land resources than were found in Middle Phase middens (Hodgetts et al., 2003). This change was interpreted by Hodgetts as an increased reliance on fallback resources when it became difficult to catch enough harp seals. This limitation in the capture of seals also limited the fat available for daily purposes (waterproofing, eating, and fuel). To compensate for this lack of fat, the Late Phase occupants might have sought alternative resources to heat their dwellings so they could keep the seal fat for other purposes (such as eating and waterproofing).

Miszaniec (2014) was able to demonstrate that the Dorset occupants of Phillip's Garden were also using wood as a source of fuel although it was probably not the main source of heat. His analysis of charcoal fragments found in certain features showed a higher density of fragments inside the structure than outside of the feature, but it could not link the concentrations to soapstone lamp fragments (Miszaniec, 2014). The procurement of wood resources to heat the houses was done according to a least-effort principle; thus, wood was likely either harvested from the forest or collected as driftwood from nearby shores (Miszaniec, 2014).

Similar to what is seen in the faunal assemblage, wood could be considered a fallback resource for the seal fat, and the Late phase entomological fauna at the site of Phillip's Garden's indicates the presence of wood and forest resources in the studied features. In the identified houses, insects associated with trees have been identified. An 
TABLE 4. Ecological preference of the different insect species, families, and genus found in the archaeological samples at Phillip's Garden.

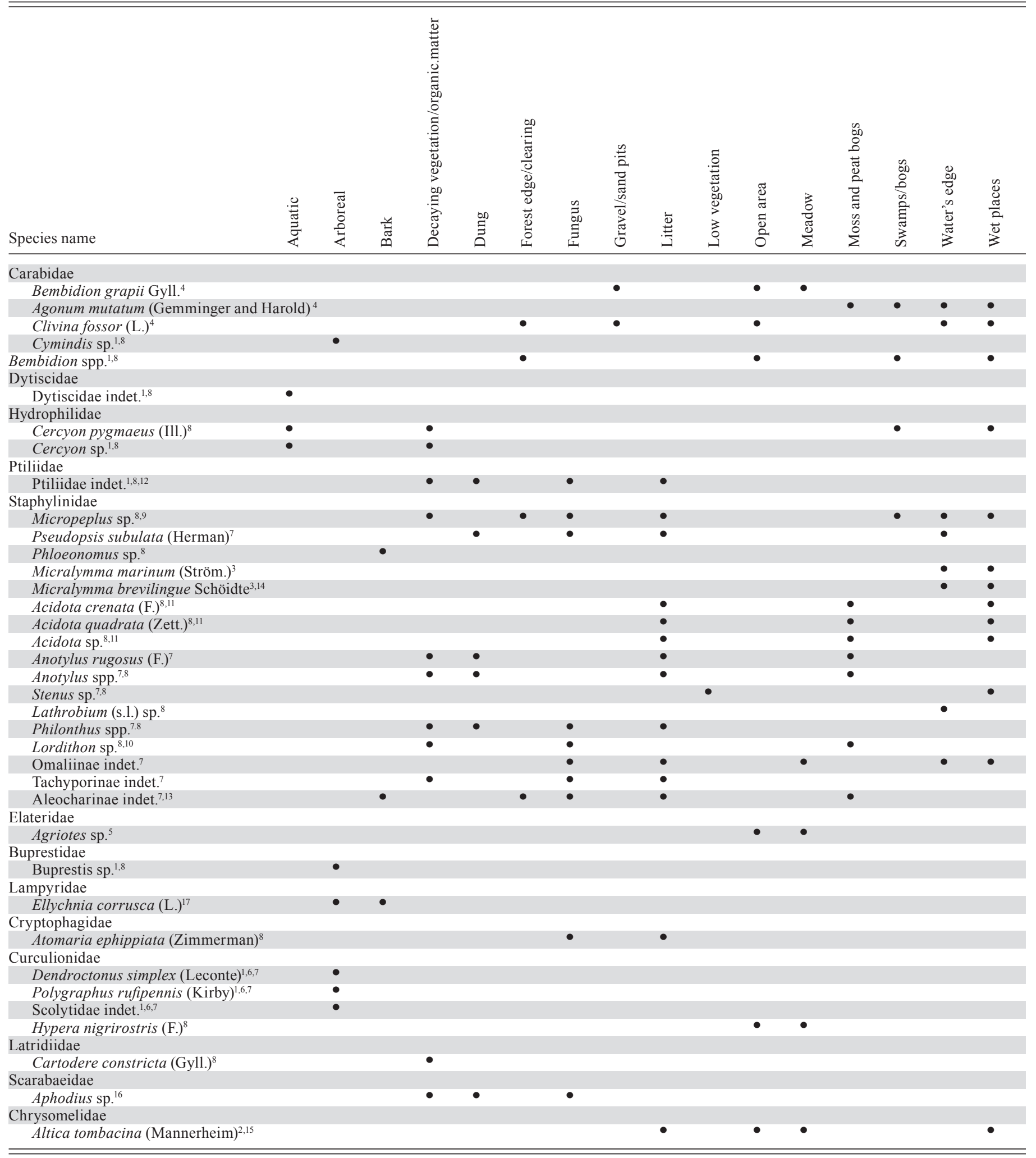

Sources: 1) Arnett, 2000; 2) Atkins, 1964; 3) Böcher, 1988; 4) Bousquet, 2010; 5) Brian, 1947; 6) Bright, 1976; 7) Brunke et al., 2011; 8) Bugguide, 2016; 9) Campbell, 1968; 10) Campbell, 1982a; 11) Campbell, 1982b; 12) Majka and Sörensson, 2010; 13) Klimaszewski et al., 2011; 14) Makarova et al., 2007; 15) Michaud, 1990; 16) Ratcliffe and Paulsen, 2008; 17) Rooney and Lewis, 2000. 


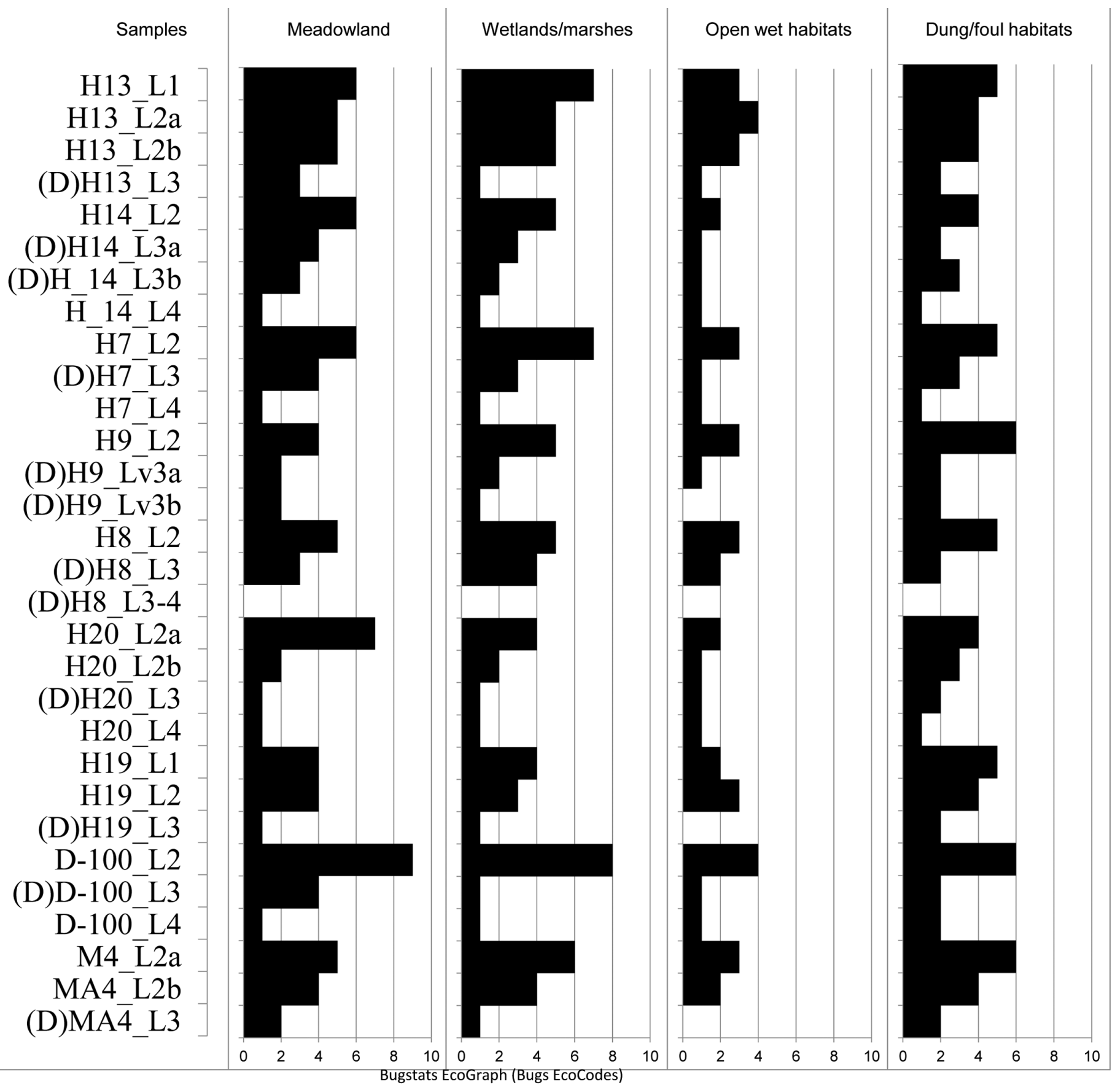

FIG. 2. Variation of the entomological fauna between the different structures and stratigraphic levels. The y-axis lists the samples, grouped by the different features that were excavated. Dorset occupation levels are identified (D). The x-axis shows the number of species associated with each ecological grouping.

example is Ellychnia corrusca, a species found on the bark of trees where the insects usually overwinter (Rooney and Lewis, 2000; Majka, 2012). Similarly, the Depression 100 occupation layer included several bark beetles (Scolytinae). These insects, absent from the abandonment phase, are dependent on the presence of trees. Current knowledge of the biology of this insect allows us to propose that the presence of these insects tends to demonstrate that the bark was still present on the wood when it was gathered. As mentioned previously, Ellychnia corrusca overwinters on the surface of the tree. During this overwintering stage and early spring, the insect moves very little on the surface of the tree, and migration between trees has not been documented (Rooney and Lewis, 2000; Majka, 2012). Winter houses, the type of structure that is documented, suggest that the wood used would have been collected and brought inside the structure during the insect's overwintering.

If we take into account the charcoal analysis undertaken by Miszaniec and his conclusion on the use of wood as a source of fuel, it appears that the Dorset from the Early and Late phases at Phillip's Garden harvested firewood from 
the adjacent forest. Although it is still possible that they harvested driftwood, the presence of Ellychnia corrusca suggests the act of harvesting trees, leaving the bark intact. The absence of forest entomological fauna during the Middle phase could be explained by the abundance of animals that were hunted by the Dorset. The site at its peak population had a greater number of hunters, who collaboratively were able to acquire a greater number of seals. The abundance of sea mammal by-products, such as fat, probably diminished the need for secondary heat sources such as wood.

\section{Dorset Impact on the Environment through Time}

In 1985, following the surveys of Phillip's Garden and the Port au Choix Peninsula, Renouf mentioned the presence of iris flowers growing in the meadow of Phillip's Garden as an indicator of the Dorset features' central depressions (Renouf, 1985). Later, she suggested that the meadow had been created by human presence (Renouf, 2011b). Environmental analyses have been undertaken previously not only at the site of Phillip's Garden, but also at other locations on the island of Newfoundland, but unfortunately little information was gained on Dorset plant use because these organic remains are poorly preserved (Deal, 2005; Renouf et al., 2009).

Contrary to botanical remains in Newfoundland, entomological remains have a good preservation rate in all of the samples used in this research. The chitin composing the exoskeleton of the insect, which is resistant to the acidic conditions generally found on the island, make it possible to recover enough remains in the occupation level and subsequent levels to offer archaeoentomological interpretation on the Dorset's occupation and impact on their surroundings (Elias, 2010).

Using the entomological remains that were recovered in the different samples, it is possible to see how the site changed from a dry, well-drained environment to an environment rich in vegetation and permanently wet. Figure 2 represents the number of insect species (lower $\mathrm{x}$-axis) associated to the different environments (upper $\mathrm{x}$-axis) through time. The samples associated with the different features are grouped on the y-axis, allowing a comparison of those features and their different levels at the same time. In every feature and sample series, the number of insect species associated with the studied environment (Meadowland, Wetland/marshes, Open wet habitat, and Dung/foul habitat) increases with each level (level 3 has more species than level 4, and level 2 has more species than level 3). Although level 4 was not excavated in every test pit, the composition of the sediment of this level, mostly sand and beach cobbles, suggests that at the time of occupation it provided good drainage and a drier environment for establishing a dwelling. These same conditions could also explain the paucity of entomological remains. As Renouf (2003) demonstrated in her review of PaleoInuit architecture, the Dorset built their houses on beach sand, where they stacked stones and elevated their house structures. Following the Dorset occupation, there is an increase in the diversity and quantity of insects found in the samples. Insects associated with a meadow environment, with signs of increased soil humidity (wetland/marshes and open wet habitat), are found in level 3 of every test pit that was analyzed, which is the Dorset occupation level of the site.

The impressive number of animal remains (i.e., 26836 bones $/ \mathrm{m}^{2}$ for Feature 2 midden), especially seal bones found in the middens and house features of the site, have for a long time shaped the narrative about the occupation at Phillip's Garden (Renouf, 1993, 2011c; Hodgetts et al., 2003; Hodgetts, 2005a, b). As has been observed on archaeological sites in the High Arctic and in Nunavik, it is possible to think that the Dorset occupation brought additional nutrients to Phillip's Garden through hunting activities and the creation of important middens. The input of nutrients to the soil at this site allowed for a richer vegetation. This bloom in vegetation is visible in the entomological fauna found in every archaeoentomological sample that was analyzed: the number of insects and diversity of species increase from the older to the more recent samples (Fig. 2).

This indication of a wet environment aligns with field observations by Renouf (1985). The change in the hydrology of this site might be due to the human presence. Level 3 of the site is described during the field work as a brown, clay-like substance that is paler in colour than the previous layer, level 2 (Wells et al., 2014).

Following the water treatment of the samples, while the fraction retrieved in the sieve did contain insects, it consisted mostly of highly degraded plant material. This clay-like substance was lying atop the beach sand on which the Dorset built their houses, and it enclosed the cultural material. It is possible to think that this organic substance played an important role in changing the hydrology of the site by preventing the proper drainage of the features, thus creating a wetter environment over the years. The addition of the seal fat might have affected the way vegetation decomposed in the feature, creating anaerobic conditions that slowed decomposition.

Our last research question concerned the intensity of occupation at the site and whether this intensity was reflected in the entomological fauna. Although the Middle phase has a more intensive occupation at the site, the entomological remains found in association with this phase do not show an increase in environmental disturbance. Houses and samples from the test pits both contained an entomological fauna with characteristics similar to remains of the previous Early phase and the following Late phase. The types of species found in the samples indicate an increase in vegetation found in the surroundings of the sites at the moment of Dorset occupation and through time: a progression to a wetter, fouler environment that is represented in all occupation phases at Phillip's Garden. 


\section{CONCLUSION}

In this paper, we used archaeoentomology to explore the visibility of the Dorset's impact on their landscape and their use of wood and plant resources through time. Insects were found in every sample analyzed except in a sterile sand level that predated the Dorset occupation. Their hard exoskeletons were well preserved in the archaeological soil, demonstrating that the use of entomological remains to study past hunter-gatherer populations, as well as how they related to and affected their landscape, is a viable exercise at Phillip's Garden. Although it was not possible to determine the intensity of the occupation through the entomological remains, other aspects of the research, such as using insect remains to infer Dorset plant use and to perceive the impact of the Dorset on their environment, were successful.

As Renouf (2011b) wrote, the meadow of Phillip's Garden was created by the human occupation at the site. Through the entomological remains that were analyzed, it is possible to see that the Dorset impact is still visible today. Without the human occupation of the site and the enriched soil caused by the processing of animal remains, the meadow would most probably have a very different appearance from the grassy field we know today.

\section{ACKNOWLEDGEMENTS}

This study would not have been possible without the support of Dr. Priscilla Renouf who directed the research during the first two years of F. Dussault's doctoral program at Memorial University of Newfoundland. The authors would like to thank the crew of the Port au Choix Archaeological Project for their help during the field season and with the sampling procedure. Dr. Patrice Bouchard and Anthony Davies are thanked for their help in the identification of entomological remains. Finally, special thanks to Drs. Lisa Hodgetts and Patricia Wells for organizing the publication of this volume.

Funding for this research project has been provided by the Social Sciences and Humanities Research Council, the Fond québécois de la recherche sur la société et la culture, the Institute of Social and Economic Research, the Provincial Archaeology Office, and the J.R. Smallwood Foundation.

\section{REFERENCES}

Amorosi, T., Buckland, P.C., Dugmore, A., Ingimundarson, J.H., and McGovern, T.H. 1997. Raiding the landscape: Human impact in the Scandinavian North Atlantic. Human Ecology 25(3):491-518. https://doi.org/10.1023/A:1021879727837

Anderson, S.L., and Freeburg, A. 2014. High latitude coastal settlement patterns: Cape Krusenstern, Alaska. Anthropology Faculty Publications and Presentations, Paper 32. http://pdxscholar.library.pdx.edu/anth_fac/32
Arnett, R.H., Jr. 2000. American insects: A handbook of the insects of America north of Mexico, 2nd ed. Boca Raton, Florida: CRC Press.

Atkins, M.D. 1964. Altica tombacina Mannerheim (Coleoptera: Chrysomelidae); a serious pest of fireweed. Proceedings of the Entomological Society of British Columbia 61:44-45.

Atkinson, T.C., Briffa, K.R., and Coope, G.R. 1987. Seasonal temperatures in Britain during the past 22,000 years, reconstructed using beetle remains. Nature 325:587-592. https://doi.org/10.1038/325587a0

Bain, A. 2001. Archaeoentomological and archaeoparasitological reconstructions at Îlot Hunt (CeEt-110): New perspectives in historical archaeology (1850-1900). British Archaeological Reports 973. Oxford: BAR Publishing.

Bain, A., and King, G. 2011. Asylum for the wayward immigrants: Historic ports and colonial settlement in the northeast. Journal of the North Atlantic 1:109-124. https://doi.org/10.3721/037.002.s110

Bain, A., and Prévost, M.-A. 2010. Environmental archaeology and landscape transformation at the seventeenth-century Ferryland site, Newfoundland. Historical Archaeology 44(3):21 - 35. https://doi.org/10.1007/BF03376801

Bakuzis, E.V., and Hansen, H.L. 1965. Balsam fir Abies balsamea (Linnaeus) Miller: A monographic review. Minneapolis: University of Minnesota Press.

Bell, T., and Renouf, M.A.P. 2008. The domino effect: Culture change and environmental change in Newfoundland, 1500-1100 cal BP. The Northern Review 28(Winter 2008): $72-94$.

-2011. By land and sea: Landscape and marine environmental perspectives on Port au Choix archaeology. In: Renouf, M.A.P., ed. The cultural landscapes of Port au Choix: Precontact hunter-gatherers of northwestern Newfoundland. New York: Springer. $21-41$. https://doi.org/10.1007/978-1-4419-8324-4_2

Bell, T., Macpherson, J.B., and Renouf, M.A.P. 2005. Late prehistoric impact on Bass Pond, Port au Choix. Newfoundland and Labrador Studies 20(1):107-129.

Bernier, J.-F. 2014. Géoarchéologie de la Rivière aux ossements (Saunitarlik), Kangiqsujuaq (Nunavik, Canada). MSc thesis, Université Laval, Québec.

Billington, R.A. 1981. Land of savagery, land of promise: The European image of the American frontier in the nineteenth century. Norman: University of Oklahoma Press.

Böcher, J. 1988. The Coleoptera of Greenland. Meddelelser om Grønland, Bioscience 26. 100 p.

Böcher, J., and Fredskild, B. 1993. Plant and arthropod remains from the Palaeo-Eskimo site on Qeqertasussuk, West Greenland. Meddelelser om Grønland, Geoscience 30. 35 p.

Boland, T. 2011. Trees \& shrubs: Newfoundland and Labrador. Portugal Cove-St Phillip's: Boulder Publications.

Bousquet, Y. 2010. Illustrated identification guide to adults and larvae of northeastern North American ground beetles (Coleoptera: Carabidae). Pensoft Series Faunistica \#90. Sofia, Bulgaria: Pensoft. 
Brian, M.V. 1947. On the ecology of beetles of the Genus Agriotes with special reference to $A$. obscurus. Journal of Animal Ecology 16(2):210-224. https://doi.org/10.2307/1496

Bright, D.E., Jr. 1976. The insects and arachnids of Canada Series, Part 2: The bark beetles of Canada and Alaska, Coleoptera: Scolytidae. Publication 1576. Ottawa: Canada Department of Agriculture.

Brunke, A., Newton, A., Klimaszewski, J., Majka, C., and Marshall, S. 2011. Staphylinidae of eastern Canada and adjacent United States. Key to Subfamilies; Staphylinidae: Tribes and Subtribes, and Species of Staphylinina. Canadian Journal of Arthropod Identification 12.110 p. http://cjai.biologicalsurvey.ca/bnkmm_12/index.html

Buckland, P.C., and Sadler, J.P. 2000. Animal remains, identification and analysis: Insects. In: Ellis, L., ed. Archaeological method and theory: An encyclopedia. New York: Garland. 21-26.

Buckland, P.I. 2007. The development and implementation of software for palaeoenvironmental and palaeoclimatological research: The Bugs Coleopteran Ecology Package (BugsCEP). Archaeology and Environment 23. Umeå: University of Umeå, Department of Archaeology and Sami Studies.

Buckland, P.I., and Buckland, P.C. 2006. BugsCEP Coleopteran Ecology Package. IGBP PAGES/World Data Center for Paleoclimatology Data Contribution Series \#2006-116. Boulder, Colorado: NOAA/NCDC Paleoclimatology Program. http://www.ncdc.noaa.gov/paleo/insect.html or http://www.bugscep.com

Bugguide. 2016. Identification, images, \& information for insects, spiders \& their kin, for the United States \& Canada. Ames: Iowa State University, Department of Entomology. http://bugguide.net/node/view/3/bgpage

Campbell, J.M. 1968. A revision of the new world Micropeplinae (Coleoptera: Staphylinidae) with a rearrangement of the world species. The Canadian Entomologist 100(3):225-267. https://doi.org/10.4039/Ent100225-3

- 1982a. A revision of the Genus Lordithon Thomson of North and Central America (Coleoptera: Staphylinidae). Memoirs of the Entomological Society of Canada 119:5-116. Ottawa: The Entomological Society of Canada.

-1982b. A revision of the North American Omaliinae (Coleoptera: Staphylinidae). The Canadian Entomologist 114(11):1003-1029. https://doi.org/10.4039/Ent1141003-11

Coope, G.R. 1959. A Late Pleistocene insect fauna from Chelford, Cheshire. Proceedings of the Royal Society of London B 151(942):70-86. https://doi.org/10.1098/rspb.1959.0051

- 1978. Constancy of insect species versus inconstancy of Quaternary environments. In: Mound, L.A., and Waloff, N., eds. Diversity of insect faunas. Oxford: Blackwell Scientific Publications. 176- 187.

Coope, G.R., and Brophy, J.A. 1972. Late Glacial environmental changes indicated by a coleopteran succession from North Wales. Boreas 1(2):97-142. https://doi.org/10.1111/j.1502-3885.1972.tb00146.x
Coope, G.R., and Osborne, P.J. 1967. Report on the coleopterous fauna of the Roman well at Barnsley Park, Gloucestershire. Transactions of the Bristol \& Gloucestershire Archaeological Society $86: 84-87$.

Damman, A.W.H. 1983. An ecological subdivision of the Island of Newfoundland. In: South, G.R., ed. Biogeography and ecology of the Island of Newfoundland. The Hague: Dr. W. Junk Publishers. 163-206.

Deal, M. 2005. Palaeoethnobotanical research at Port au Choix. Newfoundland and Labrador Studies 20(1):131-156.

Derry, A.M., Kevan, P.G., and Rowley, S.D.M. 1999. Soil nutrients and vegetation characteristics of a Dorset/Thule site in the Canadian Arctic. Arctic 52(2):204-213.

https://doi.org/10.14430/arctic923

Dickason, O.P. 1997. The myth of the savage and the beginnings of French colonialism in the Americas. Edmonton: The University of Alberta Press.

Dugmore, A.J., Church, M.J., Buckland, P.C., Edwards, K.J., Lawson, I., McGovern, T.H., Panagiotakopulu, E., Simpson, I.A., Skidmore, P., and Sveinbjarnardóttir, G. 2005. The Norse landnám on the North Atlantic islands: An environmental impact assessment. Polar Record 41(1):21 - 37. https://doi.org/10.1017/S0032247404003985

Elias, S.A., ed. 1994. Quaternary insects and their environments. Washington, D.C.: Smithsonian Institution Press.

2008. Analysis of faunal remains: Insect analysis. In: Pearsall, D.M., ed. Encyclopedia of archaeology. Amsterdam: Elsevier. $1521-1524$.

https://doi.org/10.1016/B978-012373962-9.00160-6

. 2010. Advances in Quaternary entomology. Amsterdam: Elsevier.

Erwin, J.C. 1995. An intrasite analysis of Phillip's Garden: A Middle Dorset Palaeo-Eskimo site at Port au Choix, Newfoundland. MA thesis, Memorial University of Newfoundland, St. John's.

- 2001. A prehistoric soapstone quarry in Fleur de Lys, Newfoundland. PhD thesis, University of Calgary, Calgary, Alberta.

- 2011. The changing nature and function of Phillip's Garden: A diachronic perspective. In: Renouf, M.A.P., ed. The cultural landscapes of Port au Choix: Precontact huntergatherers of northwestern Newfoundland. New York: Springer. $161-178$. https://doi.org/10.1007/978-1-4419-8324-4_8

Forbes, B.C. 1996. Plant communities of archaeological sites, abandoned dwellings, and trampled tundra in the eastern Canadian Arctic: A multivariate analysis. Arctic 49(2):141 - 154. https://doi.org/10.14430/arctic1192

Forbes, V., Dussault, F., and Bain, A. 2014. Archaeoentomological research in the North Atlantic: Past, present and future. Journal of the North Atlantic 26:1-24.

Forbes, V., Britton, K., and Knecht, R. 2015. Preliminary archaeoentomological analyses of permafrost-preserved cultural layers from the pre-contact Yup'ik Eskimo site of Nunalleq, Alaska: Implications, potential and methodological considerations. Environmental Archaeology 20(2):158-167. https://doi.org/10.1179/1749631414Y.0000000037 
Harp, E., Jr. 1950. A detective story from the far North. Dartmouth Alumni Magazine (November):17-19.

- 1951. An archaeological survey in the Strait of Belle Isle area. American Antiquity 16(3):203-220. https://doi.org/10.2307/276781

- 1976. Dorset settlement patterns in Newfoundland and southeastern Hudson Bay. In: Maxwell, M.S., ed. Eastern Arctic prehistory: Paleoeskimo problems. Memoirs of the Society for American Archaeology 31. Washington, D.C.: Society for American Archaeology. 119-138.

Hodgetts, L.M. 2005a. Dorset Palaeoeskimo harp seal exploitation at Phillip's Garden (EeBi-1), north-western Newfoundland. In: Monks, G.G., ed. The exploitation and cultural importance of sea mammals. Proceedings of the 9th Conference of the International Council of Archaeozoology, Durham, August 2002. Oxford: Oxbow Books. 62-76.

- 2005b. Using bone measurements to determine the season of harp seal hunting at the Dorset Palaeoeskimo site of Phillip's Garden. Newfoundland and Labrador Studies 20(1):91-106.

Hodgetts, L.M., Renouf, M.A.P., Murray, M.S., McCuaigBalkwill, D., and Howse, L. 2003. Changing subsistence practices at the Dorset Paleoeskimo site of Phillip's Garden, Newfoundland. Arctic Anthropology 40(1):106-120. https://doi.org/10.1353/arc.2011.0012

Howley, J.P. 1915. The Beothucks or Red Indians: The Aboriginal inhabitants of Newfoundland. Cambridge: Cambridge University Press.

Kenward, H.K. 2009. Northern regional review of environmental archaeology: Invertebrates in archaeology in the north of England. Research Department Report Series no. 12-2009. Portsmouth: English Heritage.

Kenward, H.K., Hall, A.R., and Jones, A.K.G. 1980. A tested set of techniques for the extraction of plant and animal macrofossils from waterlogged archaeological deposits. Science and Archaeology 22:3-15.

Kenward, H.K., Engleman, C., Robertson, A., and Large, F. 1985. Rapid scanning of urban archaeological deposits for insect remains. Circaea 3(3):163-172.

Klimaszewski, J., Langor, D., Pelletier, G., Bourdon, C., and Perdereau, L. 2011. Aleocharinae beetles (Coleoptera, Staphylinidae) of the province of Newfoundland and Labrador, Canada. Sofia, Bulgaria: Pensoft.

Ledger, P.M., Edwards, K.J., and Schofield, J.E. 2014. A multiple profile approach to the palynological reconstruction of Norse landscapes in Greenland's Eastern Settlement. Quaternary Research 82(1):22-37. https://doi.org/10.1016/j.yqres.2014.04.003

Lutz, H.J. 1951. The concentration of certain chemical elements in the soils of Alaskan archaeological sites. American Journal of Science 249(12):925-928. https://doi.org/10.2475/ajs.249.12.925

Majka, C.G. 2012. The Lampyridae (Coleoptera) of Atlantic Canada. Journal of the Acadian Entomological Society $8: 11-29$.
Majka, C.G., and Sörensson, M. 2010. Featherwing beetles (Coleoptera: Ptiliidae) of the Atlantic Maritime Ecozone. In: McAlpine, D.F., and Smith, I.M., eds. Assessment of species diversity in the Atlantic Maritime Ecozone. Ottawa: NRC Research Press. 433-438.

Makarova, O.L., Bieńkowski, A.O., Bulavintsev, V.I., and Sokolov, A.V. 2007. Beetles (Coleoptera) in polar deserts of the Severnaya Zemlya Archipelago. Entomological Reviews 87(9):1142-1154. https://doi.org/10.1134/S0013873807090059

McCartney, N.G. 1979. Effects of Thule Eskimos on soils and vegetation at Silumiut, N.W.T. In: McCartney, A.P., ed. Thule Eskimo culture: An anthropological retrospective. Mercury Series, Archaeological Survey of Canada Paper 88. Ottawa: National Museum of Man. 495-527.

Michaud, J.P. 1990. Observation on the biology of the bronze flea beetle Altica tombacina (Coleoptera: Chrysomelidae) in British Columbia. Journal of the Entomological Society of British Columbia 87:41 - 49.

Miszaniec, J.I. 2014. Dorset use and selection of firewood at Phillip's Garden, Northern Peninsula, Newfoundland: An application of wood identification on archaeological charcoal and contemporary driftwood. MA thesis, Memorial University of Newfoundland, St. John's.

Moore, T.R. 1986. The spatial variability of soil properties and its application to archaeology. The Canadian Geographer 30(1):80-82. https://doi.org/10.1111/j.1541-0064.1986.tb01030.x

Moore, T.R., and Denton, D. 1988. The role of soils in the interpretation of archaeological sites in northern Quebec. In: Bintliff, J., Davidson, D.A., and Grant, E.G., eds. Conceptual issues in environmental archaeology. Edinburgh: Edinburgh University Press. 25-37.

Panagiotakopulu, E. 2014. Hitchhiking across the North Atlantic Insect immigrants, origins, introductions and extinctions. Quaternary International 341:59-68.

https://doi.org/10.1016/j.quaint.2014.01.005

Panagiotakopulu, E., and Buchan, A.L. 2015. Present and Norse Greenlandic hayfields - Insect assemblages and human impact in southern Greenland. The Holocene 25(6):921 - 931. https://doi.org/10.1177/0959683615574585

Panagiotakopulu, E., and Buckland, P.C. 2013. Late Holocene environmental change in Southwest Greenland - Fossil insect assemblages from Tasiusaq. Boreas 42(1):160-172. https://doi.org/10.1111/j.1502-3885.2012.00277.x

Raghavan, M., DeGiorgio, M., Albrechtsen, A., Moltke, I., Skoglund, P., Korneliussen, T.S., Grønnow, B., et al. 2014. The genetic prehistory of the New World Arctic. Science 345(6200). $9 \mathrm{p}$.

https://doi.org/10.1126/science.1255832

Ratcliffe, B.C., and Paulsen, M.J. 2008. The Scarabaeoid beetles of Nebraska. Bulletin of the University of Nebraska State Museum 22. Lincoln: University of Nebraska State Museum.

Renouf, M.A.P. 1985. Archaeology of the Port au Choix National Historic Park: Report of 1984 field activities. Halifax: Parks Canada, Atlantic Region. 
1993. Palaeoeskimo seal hunters at Port au Choix, northwestern Newfoundland. Newfoundland Studies 9(2):185-212.

- 1999. Ancient cultures, bountiful seas: The story of Port au Choix. St. John's: Historic Sites Association of Newfoundland and Labrador.

. 2003. A review of Palaeoeskimo dwelling structures in Newfoundland and Labrador. Études/Inuit/Studies 27(12):375-416.

- 2011a. The cultural landscapes of Port au Choix: Precontact hunter-gatherers of northwestern Newfoundland. New York: Springer. https://doi.org/10.1007/978-1-4419-8324-4

- 2011b. Introduction: Archaeology at Port au Choix. In: Renouf, M.A.P., ed. The cultural landscapes of Port au Choix: Precontact hunter-gatherers of northwestern Newfoundland. New York: Springer. 1-20. https://doi.org/10.1007/978-1-4419-8324-4_1

- 2011c. On the headland: Dorset seal harvesting at Phillip's Garden, Port au Choix. In: Renouf, M.A.P., ed. The cultural landscapes of Port au Choix: Precontact hunter-gatherers of northwestern Newfoundland. New York: Springer. 131-160. https://doi.org/10.1007/978-1-4419-8324-4_7

Renouf, M.A.P., and Bell, T. 2009. Contraction and expansion in Newfoundland prehistory, AD 900-1500. In: Maschner, H., Mason, O., and McGhee, R., eds. The northern world AD 900-1400. Salt Lake City: University of Utah Press. 263-278.

Renouf, M.A.P., Bell, T., and Macpherson, J. 2009. Huntergatherer impact on subarctic vegetation: Amerindian and Palaeoeskimo occupations of Port au Choix, northwestern Newfoundland. Arctic Anthropology 46(1-2):176-190. https://doi.org/10.1353/arc.0.0031

Robinson, C.E. 2014. What lies beneath?: Three non-intrusive archaeological surveys to identify Dorset Palaeoeskimo dwellings at Phillip's Garden, Port au Choix, Newfoundland. MA thesis, Memorial University of Newfoundland, St. John's.
Rooney, J.A., and Lewis, S.M. 2000. Notes on the life history and mating behavior of Ellychnia corrusca (Coleoptera: Lampyridae). Florida Entomologist 83(3):324-334. https://doi.org/10.2307/3496351

Simpson, I.A., Dugmore, A.J., Thomson, A., and Vésteinsson, O. 2001. Crossing the thresholds: Human ecology and historical patterns of landscape degradation. Catena 42(2-4):175-192. https://doi.org/10.1016/S0341-8162(00)00137-5

Thompson, I.D., Larson, D.J., and Montevecchi, W.A. 2003. Characterization of old "wet boreal" forests, with an example from balsam fir forests of western Newfoundland. Environmental Reviews 11(S1):S23-S46. https://doi.org/10.1139/a03-012

Thompson, V.D., and Waggoner, J.C., Jr., eds. 2013. The archaeology and historical ecology of small scale economies. Gainesville: University Press of Florida.

Vickers, K., and Panagiotakopulu, E. 2011. Insects in an abandoned landscape: Late Holocene palaeoentomological investigations at Sandhavn, southern Greenland. Environmental Archaeology 16(1):49-57. https://doi.org/10.1179/146141011X12982881281911

Wells, P.J. 1988. An analysis of the butchery practices of two Palaeo-eskimo groups. Honour's thesis, Department of Archaeology, Memorial University of Newfoundland, St. John's.

2011. Ritual activity and the formation of faunal assemblages at two Groswater Palaeoeskimo sites at Port au Choix. In: Renouf, M.A.P., ed. The cultural landscapes of Port au Choix: Precontact hunter-gatherers of northwestern Newfoundland. New York: Springer. 65-89. https://doi.org/10.1007/978-1-4419-8324-4_4

Wells, P., Renouf, M.A.P., Dussault, F., Miszaniec, J., Lavers, D., and Robinson, C.E. 2014. Archaeological investigations at Phillip's Garden 2013: A program to recover chronological, entomological, and fuel charcoal data. 2013 Archaeology Review, Vol. 12. St. John's: Provincial Archaeology Office, Department of Tourism, Culture and Recreation. 12: 166-175. http://www.tcii.gov.nl.ca/pao/newsletters/pdf/Vol12-2013.pdf 